\title{
Characterization of Neurons in the CA2 Subfield of the Adult Rat Hippocampus
}

\author{
Audrey Mercer, Hayley L. Trigg, and Alex M. Thomson \\ Department of Pharmacology, The School of Pharmacy, University of London, London WC1N 1AX, United Kingdom
}

\begin{abstract}
The hippocampal cornu ammonis 2 (CA2) region is unique in being the only CA region receiving inputs from the hypothalamic supramammillary nucleus, of importance in modulating hippocampal theta rhythm, and is seizure resistant in temporal lobe epilepsy. CA2 has, however, been little studied, possibly because of its small size and difficulty encountered in defining its borders. To investigate the properties of CA2 interneurons, intracellular recordings with biocytin filling were made in adult hippocampal slices. Two types of basket cells were identified. A minority resembled those in CA1, with fast spiking behavior, vertically oriented dendrites, and axons confined to the region of origin. In contrast, the majority of parvalbumin-immunopositive CA2 basket and bistratified cells had long, horizontally oriented, sparsely spiny dendrites extending into all CA subfields in stratum oriens, adapting firing patterns and a pronounced "sag" in voltage responses to hyperpolarizing current, indicative of $I_{\mathrm{h}}$. Broad CA2 basket cells innervated all three CA subfields and could thus provide CA1 and CA2 with feedforward and CA3 with feedback inhibition. In contrast, CA2 bistratified cell axons displayed striking subfield preference, innervating stratum oriens and stratum radiatum of CA2 and CA1 but stopping abruptly at the CA2/CA3 border, implying feedforward inhibition of CA2 and CA1. These unique features suggest that CA2 is more than a transitional region between CA1 and CA3. The pronounced slow sag current of many CA2 interneurons may contribute to coordination of pyramidal cell firing during theta, whereas the fast spiking behavior of a smaller population of interneurons supports more localized gamma.
\end{abstract}

Key words: hippocampus; interneurons; CA2; basket cells; bistratified cells; morphology

\section{Introduction}

Studies in which the electrophysiological characteristics, neurochemistry, and morphology of interneurons have been correlated have identified at least 17 different classes of GABAergic cornu ammonis 1 (CA1) interneurons (Somogyi and Klausberger, 2005). In stratum pyramidale (SP), the cell bodies of four major classes are found. The largest group are the basket cells whose vertically oriented dendrites extend across all layers from stratum oriens (SO) and into stratum lacunosum moleculare (SLM) and whose axons ramify extensively in SP. CA1 basket cells can be further divided into those that express parvalbumin (PV) and typically display narrow action potentials (APs) and nonadapting firing (fast spiking cells) and those that express cholecystokinin (CCK), which commonly display broader APs and an adapting firing pattern. Axo-axonic cell dendritic arbors are similar but with distinctive arborization in alveus and SLM. Their axons ramify across only one-half of SP and the adjacent region of SO, targeting pyramidal axon initial segments. The dendrites of the fourth class, bistratified cells extend through SO and stratum radiatum (SR) but do not enter SLM. Their axons innervate py-

Received Feb. 20, 2007; revised May 21, 2007; accepted May 29, 2007.

This study was supported by Novartis Pharma (Basel, Switzerland) and the Medical Research Council (United Kingdom).

Correspondence should be addressed to Dr. Audrey Mercer, Department of Pharmacology, The School of Pharmacy, University of London, 29-39 Brunswick Square, London WC1N 1AX, UK. E-mail: audrey.mercer@ pharmacy.ac.uk.

DOI:10.1523/JNEUROSCI.1829-07.2007

Copyright $\odot 2007$ Society for Neuroscience $\quad$ 0270-6474/07/277329-10\$15.00/0 ramidal cell dendrites throughout $\mathrm{SO}$ and SR. Although a range of firing patterns has been described for these cell classes, none has been reported to display a pronounced "sag" in voltage responses to hyperpolarizing current injection. This is in strong contrast to oriens lacunosum-moleculare (OLM) cells, which have an adapting firing pattern and a pronounced sag. The thorny dendrites of CA1 OLM cells extend horizontally within $\mathrm{SO}$, and their axons ramify extensively in SLM in which they innervate the distal dendritic tufts of pyramidal cells.

The CA2 subfield has been much less studied than CA1, perhaps because it is very narrow and, in some preparations, difficult to identify. That it is a distinct, identifiable region is demonstrated by patterns of expression of cellular markers such as fibroblast growth factor 2 (Williams et al., 1996), adenosine $A_{1}$ receptor (Ochiishi et al., 1999), epidermal growth factor (Tucker et al., 1993), Purkinje cell protein 4 (Zhao et al., 2001; Lein et al., 2005), vasopressin 1 b receptor (Young et al., 2006), and $\alpha$-actinin 2 whose expression is particularly pronounced in the dendritic regions of CA2 (Wyszynski et al., 1997). Of functional significance is the fact that the CA2 region is the only hippocampal CA subfield to be innervated by the supramammillary body, a hypothalamic nucleus thought to participate in the generation of theta rhythms (Vertes and McKenna, 2000). In addition, this region is reported to be uniquely resistant to seizure generation (Sloviter, 1983). The CA2 region was also reported to contain a higher density of PV-immunopositive interneurons than either the CA1 and CA3 regions (Braak et al., 1991; Leranth and Ribak, 1991) but to suffer uniquely dramatic loss of interneurons in schizophrenia 
(Benes et al., 1998). No previous study has, however, investigated the properties of these interneurons in any detail. The aim of this study was therefore to characterize interneurons whose somata lie in SP of the CA2 region and to compare these with similar populations in CA1 using intracellular recordings, biocytin filling, and immunofluorescence.

\section{Materials and Methods}

Dual intracellular recordings and biocytin filling. Young adult male Sprague Dawley and Wistar rats weighing 90-200 g were initially anesthetized with inhaled Fluothane and then by intraperitoneal injection of Euthatal ( $\geq 60 \mathrm{mg} / \mathrm{kg}$; Merial, Harlow, UK). The rats were perfused transcardially with ice-cold oxygenated modified artificial CSF (mACSF) containing the following (in $\mathrm{mM}$ ): 248 sucrose, $25.5 \mathrm{NaHCO}_{3}, 3.3 \mathrm{KCl}$, $1.2 \mathrm{KH}_{2} \mathrm{PO}_{4}, 1 \mathrm{MgSO}_{4}, 2.5 \mathrm{CaCl}_{2}$, and 15 D-glucose (equilibrated with $95 \% \mathrm{O}_{2} / 5 \% \mathrm{CO}_{2}$ ). Slices $450-500 \mu \mathrm{m}$ thick were cut (Vibroslice; Campden Instruments, Loughborough, UK) and transferred to an interface chamber in which they were perfused with sucrose-containing ACSF for $1 \mathrm{~h}$ before switching to standard ACSF (in mM: $124 \mathrm{NaCl}, 25.5 \mathrm{NaHCO}_{3}$, $3.3 \mathrm{KCl}, 1.2 \mathrm{KH}_{2} \mathrm{PO}_{4}, 1 \mathrm{MgSO}_{4}, 2.5 \mathrm{CaCl}_{2}$, and $15 \mathrm{D}$-glucose) for an additional $1 \mathrm{~h}$ before recordings began. Ten CA2 and $21 \mathrm{CA} 1$ interneurons were recorded and filled in slices from Sprague Dawley rats $(90$ experiments) and 17 CA2 and 26 CA1 interneurons in Wistar rats (95 experiments). No electrophysiological or morphological differences between the two strains were apparent.

Intracellular recordings were made using sharp microelectrodes (tip resistance, $90-190 \mathrm{M} \Omega$ ) filled with $2 \%$ biocytin in $2 \mathrm{M} \mathrm{KMeSO}_{4}$ under current-clamp (Axoprobe; Molecular Devices, Palo Alto, CA). The electrophysiological characteristics of recorded cells were obtained from voltage responses to $400 \mathrm{~ms}$ current pulses between -0.8 and $+0.6 \mathrm{nA}$ in amplitude recorded on-line with Spike 2 (Cambridge Electronics Design, Cambridge, UK). Input resistances and membrane time constants were measured from voltage responses to $-0.2 \mathrm{nA}$ pulses. Frequency adaptation was measured as the 10 th interspike interval divided by the first. The sag was measured as the difference between the voltage response $40 \mathrm{~ms}$ after the start of a $-0.6 \mathrm{nA}$ pulse and the voltage at the end of the pulse. Rebound was measured as the difference between the voltage $40 \mathrm{~ms}$ after the end of this pulse and the baseline. Spontaneous EPSPs were counted over a period of $1 \mathrm{~min}$ and averaged (in-house software). Average spontaneous EPSP amplitude was measured as the difference between the baseline and the peak of the EPSP, the $10-90 \%$ rise time as the time taken for the EPSP to rise from 10 to $90 \%$ of its peak amplitude, and the width at half-amplitude as the time interval between the EPSP rising to $50 \%$ and falling to $50 \%$ of its peak amplitude. All data are presented as mean \pm SD.

Histology. All histological procedures used in this study have been described previously (Hughes et al., 2000). Briefly, the 450-500 $\mu \mathrm{m}$ slices were fixed overnight ( $4 \%$ paraformaldehyde, $0.2 \%$ saturated picric acid solution, and $0.025 \%$ glutaraldehyde solution in $0.1 \mathrm{~m}$ phosphate buffer). The slices were washed and gelatin embedded, and $60 \mu \mathrm{m}$ sections were cut. Sections were cryoprotected with sucrose, freeze thawed, and incubated in $1 \% \mathrm{NaBH}_{4}$ for $30 \mathrm{~min}$ as the liberated hydrogen binds to the aldehydes, reducing background and nonspecific staining and then in $10 \%$ normal goat serum for another $30 \mathrm{~min}$ to block nonspecific antibody binding. Sections were incubated overnight at $4^{\circ} \mathrm{C}$ in a mixture of mouse monoclonal anti-parvalbumin (Sigma, St. Louis, MO) or antiCCK (Center for Ulcer Research and Education, University of California, Los Angeles, Los Angeles, CA) and rabbit polyclonal anti-calbindin (CB) or anti-parvalbumin (Baimbridge and Miller, 1982) antibodies made up in $\mathrm{ABC}$ solution. Sections were then incubated for $2 \mathrm{~h}$ in a mixture of fluorescently labeled secondary antibodies, anti-mouse fluorescein isothiocyanate and goat anti-rabbit Texas Red, and avidin-7-amino-4methylcoumarin-3-acetic acid made up in PBS. Sections were mounted on slides in DABCO and studied by fluorescence microscopy. Images of fluorescence labeling were taken at $400 \times$ magnification. To visualize biocytin, sections were incubated first in $\mathrm{ABC}$ (Vector Laboratories, Burlingame, CA) and then in 3,3' diaminobenzidine (DAB; Sigma). The sections were postfixed in osmium tetroxide, dehydrated, mounted on slides (Durcupan epoxy resin; Sigma), and cured for $48 \mathrm{~h}$ at $56^{\circ} \mathrm{C}$. Neu-
A

B
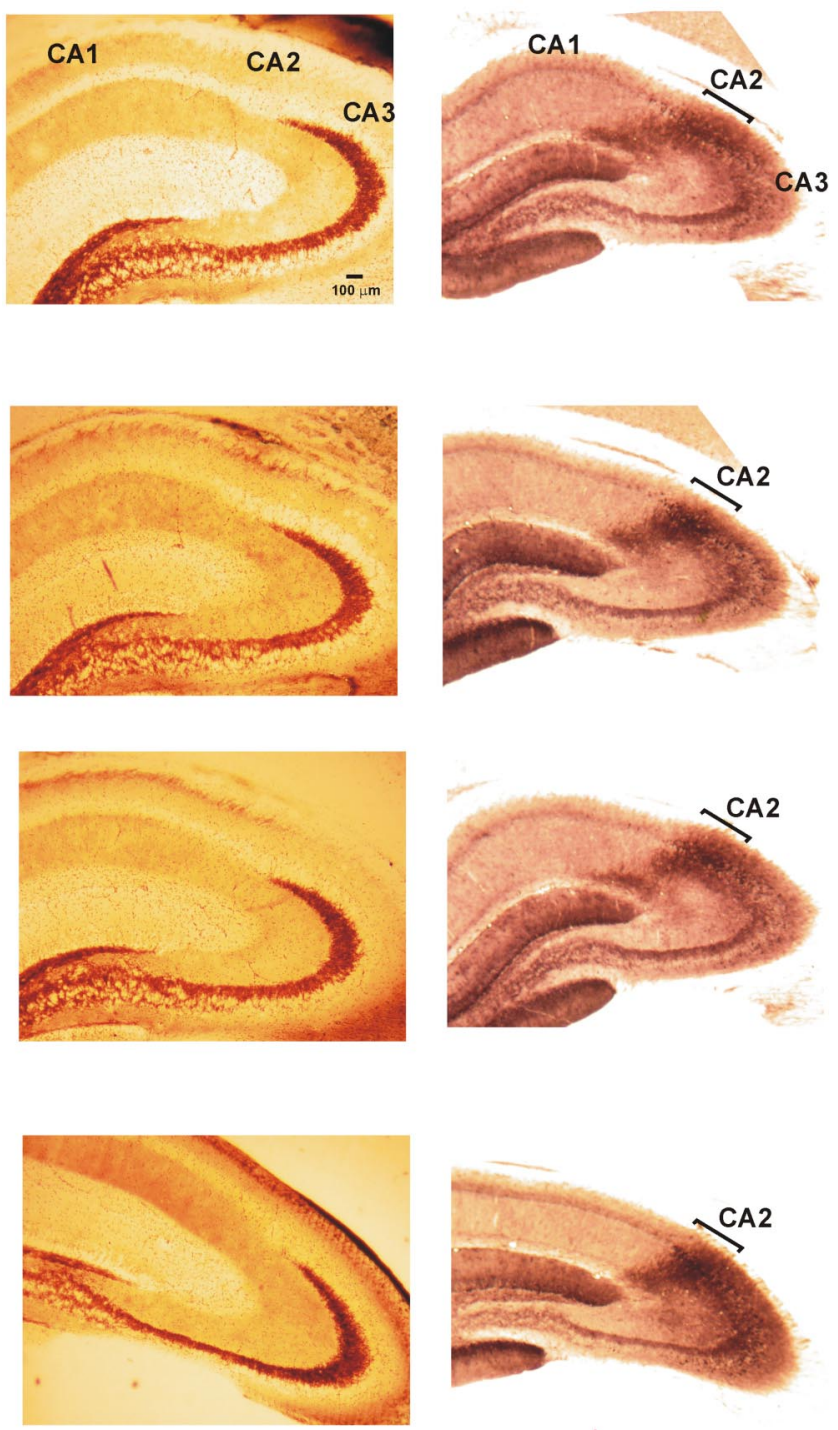

C

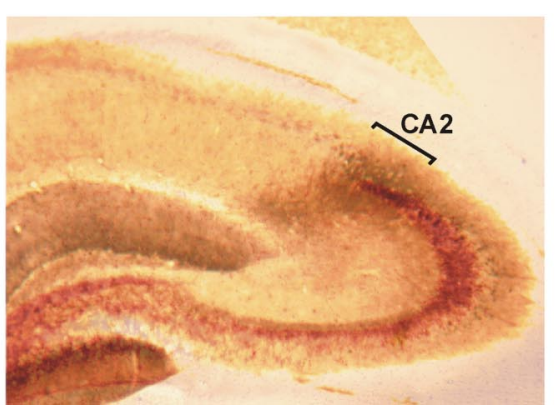

Figure 1. $A, B$, Characterization of the CA2 region using Timm staining $(\boldsymbol{A})$ and immunoperoxidase technique labeling the $\alpha$-actinin 2 protein $(B)$. Sections $50 \mu \mathrm{m}$ thick were cut from an $\sim 2500 \mu \mathrm{m}$ tissue block containing the hippocampus. Superimposition of the two stains is shown in $C$, demonstrating that the mossy fibers taper into the $C A 2$ region as defined by the $\alpha$-actinin 2 staining.

rons were drawn using a drawing tube at $1000 \times$ magnification. Some neurons were also reconstructed using Neurolucida (MBF Bioscience, Williston, VT). The total lengths of apical and basal dendrites were measured, and the number of dendritic branches contained within spheres 
A

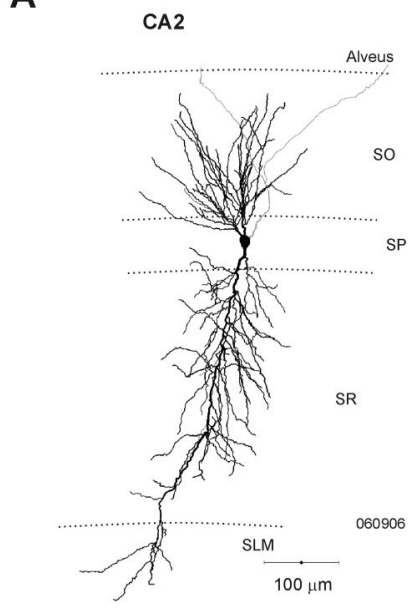

C $_{\text {CA1 }}$

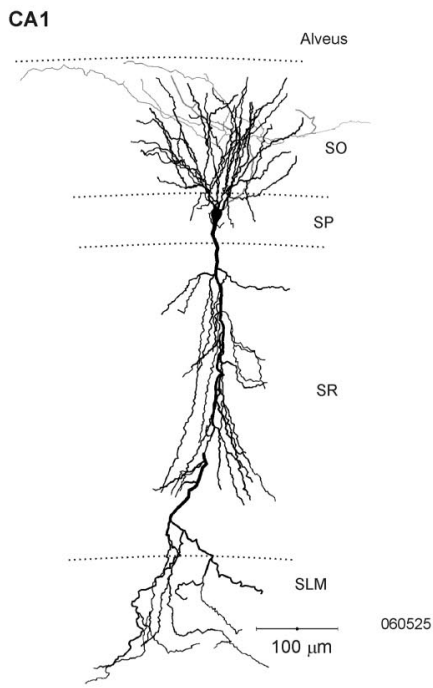

B

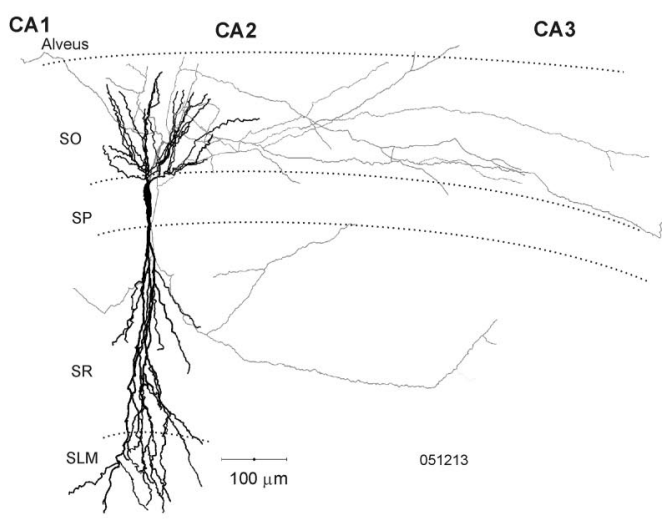

D
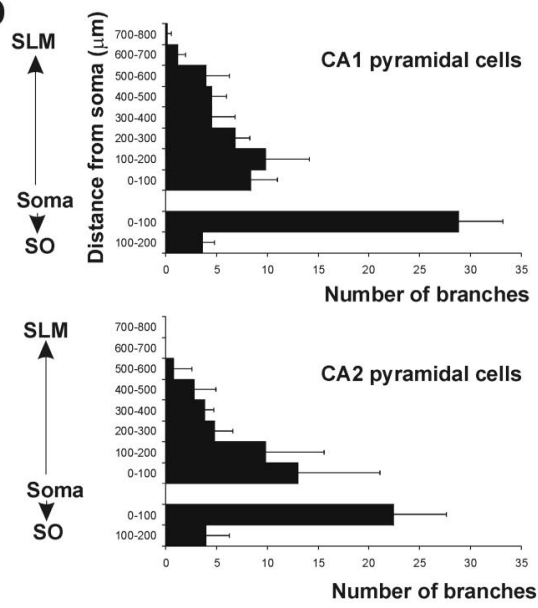

E

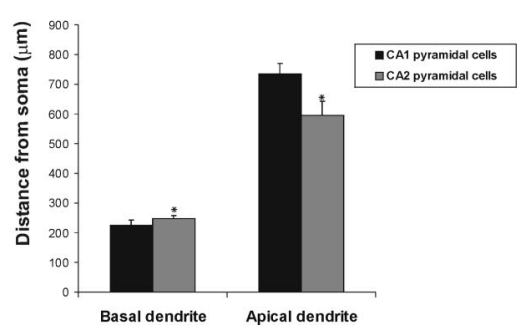

Figure 2. Morphological features of pyramidal cells recorded and filled in the CA1 and CA2 regions of the adult rat hippocampus. $A, B$, Neurolucida reconstructions of CA2 pyramidal cells. Like those in $C A 1$, the dendritic arbors of CA2 pyramidal cells (black) extended through $\mathrm{SO}$ and $\mathrm{SLM}$. Their axons (gray) arborized either exclusively in $\mathrm{SO}(\boldsymbol{A})$ or in $\mathrm{SO}$ and $\mathrm{SR}$ of the $\mathrm{CA} 2$ and $\mathrm{CA} 3$ regions (B). C, Neurolucida reconstruction of a typical CA1 pyramidal cell. The dendritic arbor (black) extended through all layers, and the axon (gray) emitted collaterals in SO. D, Number of dendritic branches against the distance from the soma of CA1 and CA2 pyramidal cells. All data are represented as mean \pm SD. E, Length of apical and basal dendrites of CA1 and CA2 pyramidal cells. CA2 pyramidal cells had longer basal and shorter apical dendrites than CA1 pyramidal cells (Mann-Whitney $U$ test, $p<0.05 ; U_{\text {basal }}=$ $\left.3, U_{\text {apical }}=0 ; n_{\mathrm{CA} 1}=6, n_{\mathrm{CA} 2}=6\right)$.

concentric with the soma and at $100 \mu \mathrm{m}$ intervals from the soma were counted. All data are represented as mean $\pm \mathrm{SD}$.

Characterization of the CA2 region. A definition of the borders of the CA2 region was essential to this study. Two techniques were used: Timm staining and immunoperoxidase labeling of the $\alpha$-actinin 2 protein. Previous studies suggested that CA2 pyramidal cells do not receive mossy fiber inputs from the dentate granule cells because they do not have thorny excrescences, implying that the CA2/CA3 border is located at the point of mossy fiber termination. Because mossy fibers contain $\mathrm{Zn}^{2+}$ at high concentration (Frederickson et al., 2000), Timm staining method may define the border. The technique used in this study has been modified from Sirvanci et al. (2003). Because zinc must be fixed immediately after brain perfusion to avoid washout, electrophysiological recordings cannot be combined with Timm staining. Adult male Wistar rats $(120-140 \mathrm{~g})$ were perfused with mACSF, the brain was removed, and a $2500 \mu \mathrm{m}$ coronal slice containing the entire hippocampus was cut (Vibroslice). This slice was placed for $2 \mathrm{~h}$ in $0.37 \%$ sodium-sulfide to fix the zinc and then submerged overnight in a $4 \%$ paraformaldehyde- $0.1 \mathrm{M}$ phosphate bufferbased fixative solution. Coronal sections $40 \mu \mathrm{m}$ thick were then cut, mounted on gelatin-coated glass slides, and allowed to dry overnight at room temperature. Sections were then submerged in a developer solution containing 300 $\mathrm{g} /$ liter of final solution gum arabic, $120 \mathrm{~mm}$ sodium citrate buffer, $17 \mathrm{~g} /$ liter of final solution hydroquinone, and $850 \mathrm{mg} /$ liter of final solution silver nitrate $\left(\mathrm{HgNO}_{3}\right)$ for $\sim 45 \mathrm{~min}$ in the dark. Sections were rinsed in running tap water for $30 \mathrm{~min}$ and placed in a 5\% sodium-thiosulfate solution for $12 \mathrm{~min}$ to stop the reaction, decrease background, and fix staining. Sections were then dehydrated in graded alcohols, cleared with $\mathrm{xy}$ lene, and coverslipped with DPX. Examples of the Timm staining are shown in Figure $1 A . \mathrm{Zn}^{2+}$ labeling is strong in stratum lucidum of $\mathrm{CA} 3$ and tapers toward the $\mathrm{CA} 2$ region.

The staining of $\alpha$-actinin 2 was also used to define the borders of the CA2 region (Fig. $1 B$ ). Although this protein is expressed in pyramidal cell dendrites and some interneurons of all hippocampal regions, the strongest staining is present in CA2 and the molecular layer of the dentate gyrus (Wyszynski et al., 1997; Ratzliff and Soltesz, 2001). One adult male Wistar rat (135 g) was perfused with mACSF. The brain was removed, and $500 \mu \mathrm{m}$ sections were cut (Vibroslice) and fixed overnight (4\% paraformaldehyde, $0.2 \%$ saturated picric acid, and $0.025 \%$ glutaraldehyde in $0.1 \mathrm{~m}$ phosphate buffer). Sections $50 \mu \mathrm{m}$ thick were cut (Vibratome), cryoprotected with sucrose, and freeze thawed. Endogenous peroxidase activity was blocked using $1 \% \mathrm{H}_{2} \mathrm{O}_{2}$ for 30 min. Sections were then incubated in $10 \%$ normal goat serum for $30 \mathrm{~min}$ and then overnight in the primary antibody solution (mouse anti- $\alpha$ actinin, clone EA-53, 1:5000; Sigma) made up in PBS. Sections were incubated with a labeled polymer (mouse Dako EnVision Plus HRP kit; Dako, Ely, UK) for $3 \mathrm{~h}$. A standard visualization of the staining was made using DAB as a substrate. Sections were then dehydrated, embedded in resin, mounted on slides, and cured for $48 \mathrm{~h}$ at $56^{\circ} \mathrm{C}$.

Drawings of interneurons recorded and filled in the CA2 subfield were superimposed on digital images of the $\alpha$-actinin 2 staining in a section from the same frontocaudal level. As defined by this staining profile, stratum pyramidale of the CA2 region was found to be $400-475 \mu \mathrm{m}$ wide throughout the adult rat hippocampus. Figure $1 C$ illustrates images of the two techniques superimposed revealing that the CA3 region (defined by mossy fiber terminals) tapers into the CA2 region (defined by $\alpha$-actinin 2 immunoperoxidase staining).

\section{Results}

Comparison of dendritic and axonal arbors of CA2 and CA1 pyramidal cells

Twenty CA1 and 18 CA2 pyramidal cells were drawn using a drawing tube. In addition, five CA1 and six CA2 pyramidal cells were drawn using Neurolucida for additional analysis (Fig. 2). 
Typically, one apical dendrite emerged from the soma of CA1 pyramidal cells and emitted apical oblique branches in SR before terminating in a tuft in SLM (Fig. 2C). Several basal dendrites extended to $\mathrm{SO}$ and often reached the alveus. The axons of these $\mathrm{CA} 1$ cells typically emerged from the soma and arborized within SO. CA2 pyramidal cells resembled the CA1 pyramidal cells in that their dendrites extended through all layers of the CA2 region and did not display thorny excrescences (Fig. $2 A, B)$. No significant difference in the number of dendritic branches emanating from the soma of the CA1 and CA2 pyramidal cells was apparent (Fig. 2D). However, CA2 pyramidal cells were shorter than those of the CA1 region (MannWhitney $U$ test, $p<0.05 ; U=0 ; n_{\mathrm{CA} 1}=5$, $n_{\mathrm{CA} 2}=6$ ). The mean total dendritic length of CA1 and CA2 pyramidal cells was $958 \pm$ 40 and $841 \pm 40 \mu \mathrm{m}$, respectively. The basal dendrites of CA2 pyramidal cells were longer than those of CA1 pyramidal cells (Mann-Whitney $U$ test, $p<0.05$; $U=3$ ), but their apical dendrites were shorter (Mann-Whitney test, $p<0.05$; $U=0$ ) (Fig. 2E).

The axons of CA2 pyramidal cells emerged from the soma and arborized either in $\mathrm{SO}$ of CA2 with some branches reaching CA1 or CA3 $(n=14)$ (Fig. $2 A)$ or, in contrast to CA1 pyramidal axons, in SO and SR of CA1, CA2, and CA3 $(n=4)$ (Fig. 2B). The axons did not appear to be myelinated and, in contrast to some pyramidal cell axons in CA1, did not enter the white matter of the alveus.

\section{Dendritic and axonal arbors of CA2 basket cells: comparison with those of the CA1 subfield}

Of the 82 CA1 and 72 CA2 interneurons recorded, 24 CA1 and 20 CA2 interneurons were identified as basket cells. All CA1 basket cells in this study displayed similar dendritic and axonal patterns and resembled those reported previously (Sik et al., 1995; Freund and Buzsaki, 1996; Ali et al., 1998, 1999; Pawelzik et al., 1999). They had relatively narrow vertically oriented dendritic arbors that extended through $\mathrm{SO}$, in some cases entering the alveus, and through SR and into SLM (Fig. $3 A)$. All dendrites were aspiny and were often beaded. CA1 basket cell axons whose major branches were often myelinated, ramified extensively in $\mathrm{SP}$, and, in some cases, in the most proximal regions of SR and SO (previously described as "wide arbor basket cells") (Buhl et al., 1996; Freund and Buzsaki, 1996; Ali et al., 1998; Pawelzik et al., 1999, 2002). The majority of these CA1 basket cells were found to be PV immunopositive and CB immunonegative (16:23).

Like those in CA1, CA2 basket cells had dendrites that ex-

B

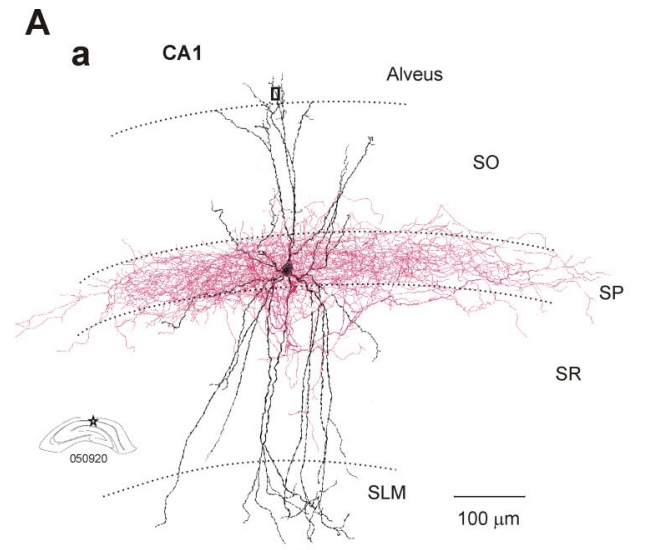

b
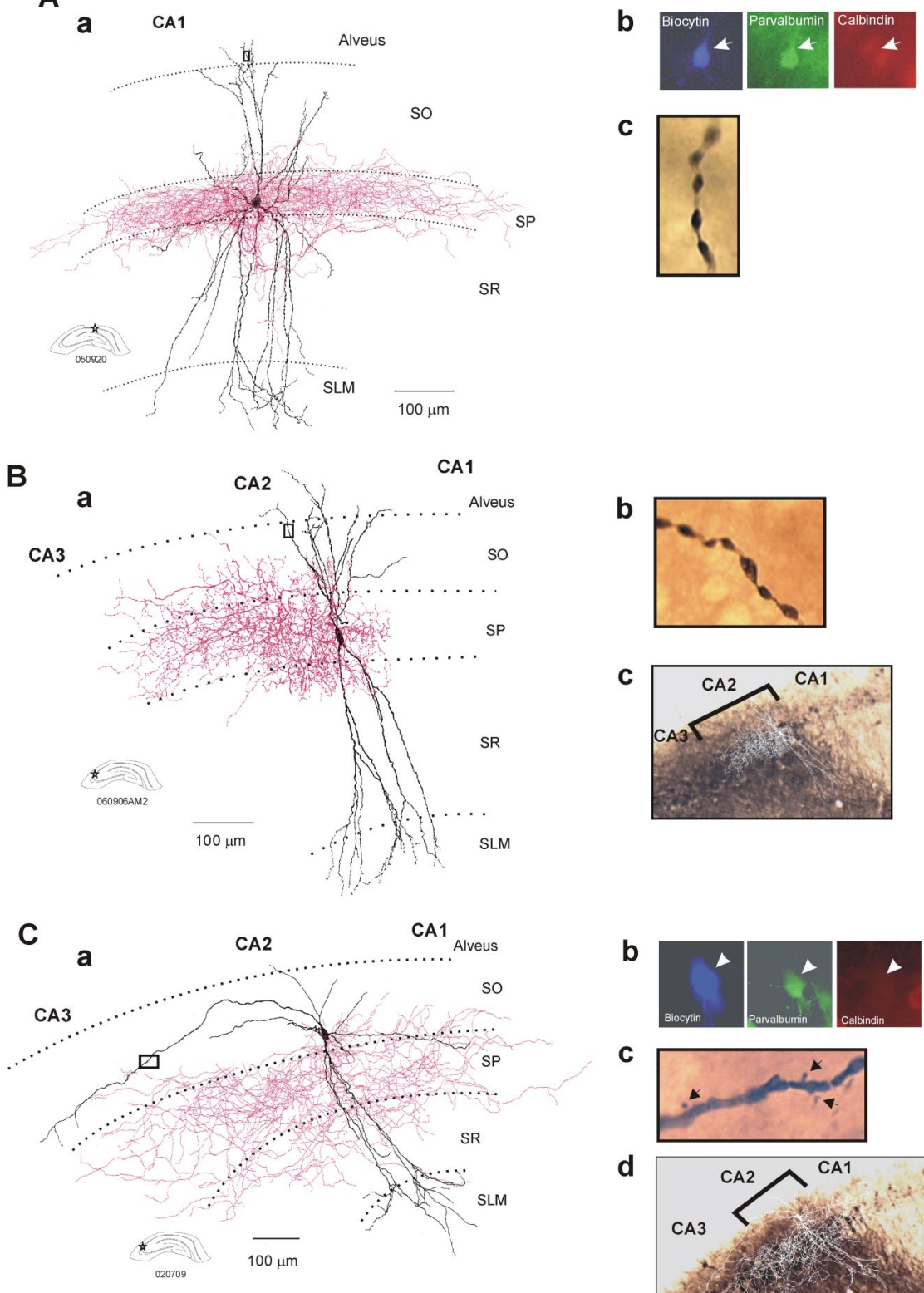

b

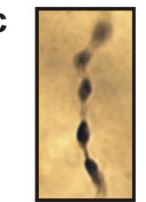

b

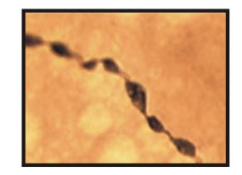

C
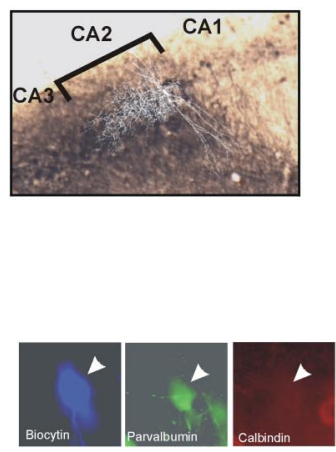

C

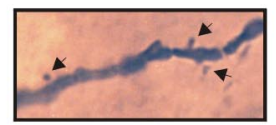

d

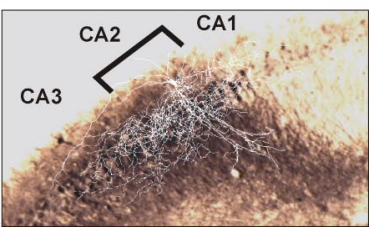

Figure 3. Dendritic and axonal arbors of basket cells recorded and filled in the CA1 and CA2 regions. Aa, Reconstruction of a CA1 basket cell (drawing tube, $1000 \times$ ). The dendrites of (A1 basket cells (in black) extended through SO and SLM. The axonal arbor (in red) was almost entirely confined to SP of the CA1 region. $\boldsymbol{A} \boldsymbol{b}$, The basket cell was PV immunopositive and CB immunonegative. $\mathbf{A c}$, Image of a portion (black square in $\mathbf{A a}$ ) of a distal dendrite that was beaded and aspiny. $\mathbf{B a}$, Reconstruction using a drawing tube $(1000 \times)$ of a CA2 basket cell that was confined to the CA2 region. The dendrites are in black, and the axon is in red. $\boldsymbol{B} \boldsymbol{b}$, Image of a portion (black square in $\mathbf{B a}$ ) of a distal dendrite that was beaded and aspiny. $B \boldsymbol{C}$, Superimposition of the drawing of the basket cell on an image of the $\alpha$-actinin 2 staining confirmed that the interneuron was confined to the CA2 region. Ca, A CA2 basket cell was reconstructed using a drawing tube $(1000 \times)$. The dendritic tree of this basket cell (in black) extended radially through all layers of the $C A 2$ region and horizontally in $S 0$ and $S P$ of the $C A 2$ and $C A 3$ regions. One horizontal dendrite also reached the $C A 1$ region. The axon (in red) extended to the CA3 and CA1 regions. $C \boldsymbol{b}$, The basket cell was PV immunopositive and CB immunonegative. (c, Spines (arrows) were present in the distal part of the horizontally oriented dendrites (black square in $\mathbf{C a}$ ). Cd, Superimposition of the drawing of the basket cell on an image of the $\alpha$-actinin 2 staining.

tended through $\mathrm{SO}$, sometimes entering the alveus, and through SR and into SLM (Fig. $3 B, C$ ). Again, their major axonal branches were often myelinated, and their axonal arbors ramified extensively in SP and, in some cases, also in proximal SO and SR. Six CA2 basket cells resembled CA1 basket cells further in that their dendritic arbors were narrow and both dendrites and axons were confined to the region of origin (Fig. 3B, Table 1). The majority of 
Table 1. Dendritic and axonal patterns of basket and bistratified cells recorded in the CA1 and CA2 subfields of the adult rat hippocampus

\begin{tabular}{llll}
\hline Cell type & Dendritic height $(\mu \mathrm{m})$ & Dendritic width $(\mu \mathrm{m})$ & Axonal width $(\mu \mathrm{m})$ \\
\hline CA1 basket cells $(n=12)$ & $616 \pm 72$ & $319 \pm 77$ & $718 \pm 163$ \\
CA2 basket cells wide arbor $(n=10)$ & $581 \pm 137$ & $537 \pm 126$ & $879 \pm 172$ \\
CA2 basket cells narrow arbor $(n=6)$ & $628 \pm 69$ & $331 \pm 60$ & $551 \pm 66$ \\
CA1 bistratified cells $(n=6)$ & $567 \pm 101$ & $320 \pm 89$ & $808 \pm 254$ \\
CA2 bistratified cells $(n=4)$ & $502 \pm 70$ & $462 \pm 173$ & $742 \pm 160$ \\
\hline
\end{tabular}

The dendritic width of the second type of CA2 basket cells was significantly broader than that of the first type of CA2 basket cells and of CA1 basket cells (Mann-Whitney $U$ test, $p<0.05 ; U=0$ ). Their axons extended farther than those of $C A 2$ basket cells with narrow dendritic arbor (Mann-Whitney $U$ test, $p$ $<0.05 ; U=0)$.

these CA2 basket cells were PV immunopositive and CB immunonegative (4:6).

The majority of basket cells in CA2 were, however, unlike those in CA1 in several respects. Their dendrites in SO extended horizontally into all three CA subfields, and the distal portions of these horizontal dendrites were sparsely spiny (Fig. 3C). The total dendritic width of these cells was significantly broader than that of the other type of CA2 basket cells or of CA1 basket cells (Mann-Whitney $U$ test, $p<0.005 ; U=0$ ) (Table 1). Their axonal arbors were also broader than those of the first type of CA2 basket cells (Mann-Whitney $U$ test, $p<0.05 ; U=0$ ) (Table 1) and extended into all CA subfields. Eight of 10 of these CA2 basket cells were PV immunopositive and CB immunonegative; immunofluorescence results for the remaining two were ambiguous.

The dendrites of 15 CA1 and 18 CA2 basket cells (12 with wide and 6 with narrow dendritic arbors) were reconstructed, and their dendritic trees were analyzed in the same way as the pyramidal cells (Fig. 2). No significant difference was apparent between regions or between the two types of CA2 basket cells. The total lengths of apical and basal dendrites were also similar across subtypes. It was therefore the orientation, not the number or length of dendrites, that differed.

\section{Dendritic and axonal arbors of CA2 bistratified cells}

Seven CA1 and five CA2 interneurons were identified as bistratified cells. CA2 bistratified cells also had distinctive features (Fig. 4). Their radially oriented dendrites resembled CA1 bistratified cells (Fig. 4A), in that they extended through SO and SR without entering SLM (Fig. 4B,C). However, in two of these cells, the dendrites extended much further horizontally into all three CA subfields (Fig. 4C), and these horizontally oriented dendrites were sparsely spiny. There was, however, no significant difference in the number of branches or the length of apical and basal dendrites when CA1 and CA2 bistratified cells were compared. CA2 bistratified axons were highly selective in the subfields innervated. They ramified almost exclusively in SO and SR of the CA2 and CA1 regions, few if any branches extending a few micrometers into CA3 (Fig. $4 B, C$ ). From the soma, the axons of CA2 bistratified cells extended $163 \pm 15 \mu \mathrm{m}$ toward CA3 and $571 \pm$ $168 \mu \mathrm{m}$ toward CA1. For comparison, CA1 bistratified cell axons were more balanced, with branches $408 \pm 178 \mu \mathrm{m}$ toward CA3 and $403 \pm 158 \mu \mathrm{m}$ toward the subiculum.

Three of five CA2 bistratified cells tested were PV immunopositive and CB immunonegative; immunofluorescence results for the remaining two were ambiguous.

\section{Firing pattern of CA2 interneurons}

The firing patterns of interneurons in the CA1 and CA2 regions were assessed from voltage responses to injected current pulses
(Table 2, Figs. 5, 6). CA1 basket and bistratified cells typically displayed fast spiking behavior with little spike frequency adaptation and no sag in their voltage response to hyperpolarizing current (Figs. 5A, 6A). The majority of basket and bistratified cells in CA2 that had narrow dendritic arbors were similar (Figs. 5B, $6 B)$. However, in contrast to CA1 basket cells, some displayed a delayed or stuttering firing pattern. In addition, CA2 basket cells with narrow dendritic arbors often displayed short interspike interval spike doublets during continuous firing elicited by suprathreshold current injection.

In striking contrast, CA2 basket and bistratified cells with broad, horizontally oriented dendrites in SO displayed significant spike frequency adaptation, a pronounced sag in voltage responses to hyperpolarizing current pulses, and rebound on their cessation (Figs. 5C, 6C).

These electrophysiological data revealed features of CA2 basket and bistratified cells that are quite distinct from those described in CA1 in this and previous studies (Ali et al., 1998; Pawelzik et al., 2002). The comparison of the dendritic and axonal arborization and firing patterns of interneurons in the CA1 and CA2 regions suggested a significant correlation between the presence of a sag and the frequency adaptation (Spearman's test, $r=0.51 ; \alpha=0.05$ ) and also between the presence of a sag and the dendritic width of interneuron (Spearman's test, $r=0.8 ; \alpha=$ 0.05 ) (Fig. 7). These correlations were independent of cell type defined by more conventional criteria. Interneurons with a wide dendritic arbor consistently displayed a sag and rebound in response to hyperpolarizing current injection, whereas interneurons with a narrow dendritic tree did not.

\section{Spontaneous synaptic activity in interneurons of the CA1 and CA2 subfields}

The frequency and time course of spontaneous EPSPs received by CA1 and CA2 interneurons are summarized in supplemental Table 1 (available at www.jneurosci.org as supplemental material). CA2 interneurons presented a higher level of spontaneous synaptic activity than those in SP of CA1 (Mann-Whitney $U$ test, $p<0.05$; $U=7)$. The highest levels of spontaneous activity were displayed by interneurons with broad dendritic arbors. The time course of spontaneous EPSPs in CA1 and CA2 basket and bistratified cells was similar, although on average CA2 basket cells received larger spontaneous EPSPs than CA1 basket cells (Mann-Whitney $U$ test, $p<0.05 ; U=8$ ).

\section{Discussion}

The characterization of hippocampal interneurons and their contribution to hippocampal circuitry continue to be important questions if we are to gain a better understanding of network activity. Here, intracellular recordings with biocytin filling characterized the structures and electrophysiological properties of neurons in CA2 and compared these characteristics with those of neurons of CA1. Striking differences, particularly in the properties of interneurons, were apparent.

\section{Characterization of CA2 pyramidal cells}

CA2 pyramids had shorter dendrites and, unlike CA1 pyramids, axons that could arborize in SR as well as in SO of CA1, CA2, and CA3. Previous Golgi studies (Lorente de No, 1934) had demonstrated that CA2 pyramidal axon collaterals arborize in SO. In- 
tracellular dye injection studies in vivo and in vitro also reported axon collaterals in SO and not in SR (Ishizuka et al., 1990, 1995). However, a subsequent in vivo intracellular labeling study in rat hippocampus with recovery after 3 d (Tamamaki et al., 1988) demonstrated CA2 axons with two branches projecting essentially separately, to SO and SR of CA1, with some branches extending to $\mathrm{CA} 3 \mathrm{~b}$ and $\mathrm{CA} 3 \mathrm{c}$. In this study, some CA2 pyramids had axons arborizing in SO and SR of CA1, CA2, and CA3, but the majority, like CA1 pyramidal axons, arborized exclusively in SO. This difference could, however, be attributable to part of the axon being cut during the slicing. CA2 pyramids are innervated by Schaffer collaterals in SO and SR and by input from entorhinal cortex in SLM (Sekino et al., 1997; Bartesaghi and Guessi, 2004; Bartesaghi et al., 2006). It remains controversial, however, whether CA2 pyramids also receive mossy fiber input from the dentate gyrus, but in agreement with Gaarskjaer (1986), the superimposition of the Timm staining and $\alpha$-actinin 2 labeling in this study demonstrates mossy fibers tapering into CA2.

\section{Dendritic and axonal arbors of CA2 basket cells}

The largest population of interneurons recorded and filled in CA2 consisted of basket cells. Like CA1 basket cells (Sik et al., 1995; Buhl et al., 1996; Freund and Buzsaki, 1996; Ali et al., 1998, 1999; Pawelzik et al., 1999, 2002), CA2 basket cells recorded in SP or proximal SO had dendrites that extended through SO, sometimes entering the alveus, and through SR and into SLM. Their axons arborized extensively in SP, in some cases ramifying also in proximal $\mathrm{SO}$ and $\mathrm{SR}$.

Two distinct types of CA2 basket cells were identified. The first resembled those of CA1 with a narrow arbor of aspiny dendrites and axons confined to the region of origin. In contrast, the second type of CA2 basket cells had axons and dendrites that extended into all three CA subfields, and the distal portions of these horizontal dendrites were sparsely spiny.

Because CA2 receives direct inputs from CA3 (Sekino et al., 1997) and from entorhinal cortex (Bartesaghi and Gessi, 2004; Bartesaghi et al., 2006), the vertically oriented dendrites of both types of CA2 basket cells are positioned to receive both inputs. In addition, CA2 basket cells with horizontal dendrites may receive inputs from pyramidal cells of all three regions. This may explain the high levels of spontaneous synaptic activity recorded in these cells compared with those of CA1. The axons of these CA2 basket cells also extended into all CA regions, suggesting that these cells provide "feedback" inhibition to CA3 as well as
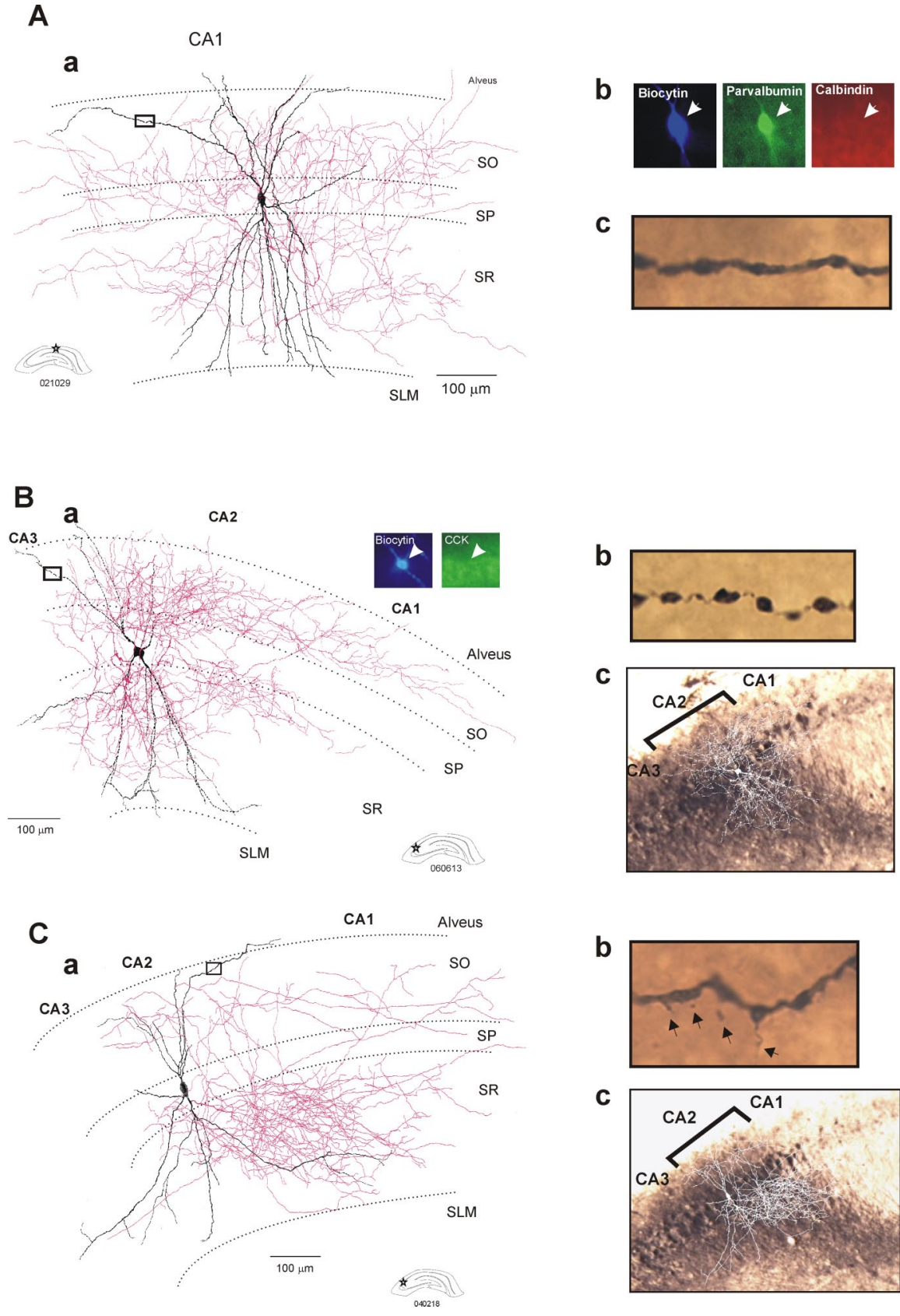

b
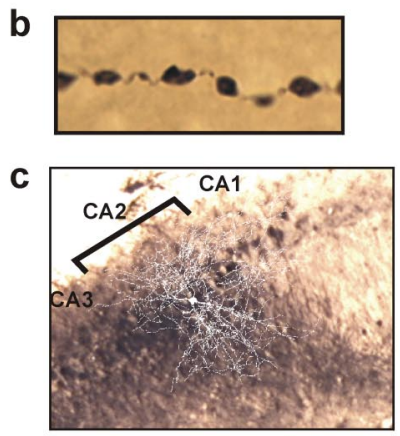

Figure 4. Dendritic and axonal patterns of bistratified cells recorded and filled in the CA1 and CA2 regions. Aa, Reconstruction of a typical bistratified cell in the CA1 region. The dendritic arbor (in black) extended radially through SO and SR but did not enter SLM. The axon (in red) arborized mainly in S0 and SR of the CA1 region. $\boldsymbol{A} \boldsymbol{b}$, The bistratified cell was PV immunopositive and CB immunonegative. $\mathbf{A c}$, Image of a portion (black square in $\boldsymbol{B a}$ ) of a distal dendrite that was beaded and aspiny. $\boldsymbol{B a}$, Reconstruction of a CA2 bistratified cell using a drawing tube. This cell presented a narrow dendritic arbor (in black) that extended from $\mathrm{SO}$ to $\mathrm{SR}$ without entering SLM. The axon (in red) was strongly polarized and arborized mainly in SO and SR of CA2 and CA 1 but did not enter CA3. The bistratified cell was CCK immunonegative. $\boldsymbol{B} \boldsymbol{b}$, Image of a portion (black square in $\boldsymbol{B} \boldsymbol{a}$ ) of a distal dendrite that was beaded and aspiny. $\mathbf{B C}$, Superimposition of the drawing of the bistratified cell on an image of the $\alpha$-actinin 2 staining. $\mathbf{C a}$, Reconstruction of another $\mathrm{CA} 2$ bistratified cell. This interneuron presented a broad dendritic arbor (in black) that extended to the CA1 and CA3 regions. The axonal arbor of this bistratified cell (in red) was strongly polarized ramifying in $\mathrm{SO}$ and $\mathrm{SR}$ of the CA2 and $\mathrm{CA} 1$ regions but not $\mathrm{CA}$. $\mathbf{C} \boldsymbol{b}$, Image of a portion (black square in $\mathbf{C a}$ ) of a distal dendrite that presented spines (arrows). $\mathbf{C} \boldsymbol{c}$, Superimposition of the drawing of the bistratified cell on an image of the $\alpha$-actinin 2 staining.

"feedforward" inhibition to CA1 and play therefore a unique role in coordinating the hippocampal circuitry.

Dendritic and axonal characteristics of CA2 bistratified cells CA2 bistratified cells also had distinctive features. Their dendrites, like those of CA1 bistratified cells (Buhl et al., 1996; 
Table 2. Electrophysiological characteristics of interneurons of the CA1 and CA2 regions

\begin{tabular}{|c|c|c|c|c|c|c|c|c|c|}
\hline Cell type & $\begin{array}{l}\text { Resting MP } \\
(\mathrm{mV})\end{array}$ & $\begin{array}{l}\text { Input resistance } \\
(\mathrm{M} \Omega)\end{array}$ & $\begin{array}{l}\text { Membrane time } \\
\text { constant (ms) }\end{array}$ & $\begin{array}{l}\text { Frequency } \\
\text { adaptation }\end{array}$ & Sag $(m V)$ & $\begin{array}{l}\text { Rebound } \\
\text { (mV) }\end{array}$ & $\begin{array}{l}\text { AP amplitude } \\
\text { (mV) }\end{array}$ & $\begin{array}{l}\text { APHW } \\
\text { (ms) }\end{array}$ & $\mathrm{AHP}(\mathrm{mV})$ \\
\hline \multicolumn{10}{|l|}{ CA1 basket } \\
\hline cells $(n=10)$ & $-72.1 \pm 2.2$ & $69.7 \pm 20.5$ & $10.2 \pm 4.1$ & $1.4 \pm 0.5$ & $0.1 \pm 0.2$ & $0.3 \pm 0.3$ & $59.8 \pm 8.4$ & $0.5 \pm 0.1$ & $13.6 \pm 5$ \\
\hline $\begin{array}{l}\text { CA2 basket } \\
\text { cells with wide }\end{array}$ & & & & & & & & & \\
\hline $\operatorname{arbor}(n=10)$ & $-74.9 \pm 5.6$ & $111.8 \pm 36.7$ & $12.6 \pm 4.2$ & $2.9 \pm 1.9$ & $20.2 \pm 9.4$ & $13.2 \pm 9.2$ & $65.5 \pm 7.1$ & $0.6 \pm 0.1$ & $19.5 \pm 9$ \\
\hline $\begin{array}{l}\text { CA2 basket } \\
\text { cells with }\end{array}$ & & & & & & & & & \\
\hline $\begin{array}{l}\text { narrow arbor } \\
(n=6)\end{array}$ & $-71.2 \pm 4$ & $77 \pm 19.3$ & $8.2 \pm 3.2$ & $1.3 \pm 0.4$ & $0.1 \pm 0.1$ & $0.2 \pm 0.5$ & $62.7 \pm 9$ & $0.5 \pm 0.1$ & $22 \pm 5.1$ \\
\hline CA1 & & & & & & & & & \\
\hline $\begin{array}{l}\text { bistratified cells } \\
(n=5)\end{array}$ & $-73.6 \pm 2.4$ & $58.6 \pm 12.7$ & $13.8 \pm 0.9$ & $1.4 \pm 0.05$ & $0.2 \pm 0.1$ & $0.4 \pm 0.1$ & $62.9 \pm 10.8$ & $0.6 \pm 0.2$ & $16.8 \pm 8.2$ \\
\hline $\begin{array}{l}\text { CA2 } \\
\quad \text { bistratified cells } \\
\text { with wide }\end{array}$ & & & & & & & & & \\
\hline $\operatorname{arbor}(n=2)$ & $-76 /-73$ & $83.3 / 120$ & $25 / 12.5$ & $2.7 / 3$ & $5 / 34$ & $6.6 / 20$ & $69 / 60.1$ & $0.7 / 0.6$ & $18 / 11.5$ \\
\hline $\begin{array}{l}\text { CA2 } \\
\text { bistratified cells } \\
\text { with narrow }\end{array}$ & & & & & & & & & \\
\hline $\operatorname{arbor}(n=3)$ & $-72.7 \pm 1.1$ & $83.3 \pm 16.7$ & $13.7 \pm 10$ & $1.14 \pm 0.5$ & $0.1 \pm 0.1$ & $0.2 \pm 0.2$ & $65.2 \pm 7.8$ & $0.4 \pm 0.1$ & $14.4 \pm 11.8$ \\
\hline
\end{tabular}

MP, Membrane potential; HW, half-width; AHP, afterhyperpolarization.

Freund and Buzsaki, 1996; Ali et al., 1998; Pawelzik et al., 1999, 2002), extended through SO and SR without entering SLM, suggesting that these cells receive Schaffer collaterals but not inputs from entorhinal cortex. The dendrites of two of these cells, however, extended much further horizontally than those of CA1 bistratified cells, into all three CA subfields. Like CA2 basket cells with broad dendritic arbors, the distal portions of their horizontal dendrites were sparsely spiny. However, unlike wide CA2 basket cells, CA2 bistratified cells displayed a striking subfield pref-

erence. Their axons innervated CA2 and CA1 but stopped abruptly at the CA2/CA3 border. Thus, unlike CA2 basket cells with broad dendritic arbors, these cells may provide primarily feedforward inhibition to CA2 and CA1.

\section{CA2 interneurons with wide dendritic arbors displayed striking electrophysiological properties}

CA2 basket and bistratified cells with morphological characteristics similar to those of CA1 (i.e., narrow dendritic arbors) displayed comparable electrophysiological properties. In striking contrast, CA2 basket and bistratified cells with dendrites extending into all three CA subfields displayed significant spike frequency adaptation and a pronounced sag in voltage responses to hyperpolarizing current and a subsequent rebound depolarization. Electrophysiologically, therefore, they differed markedly from CA1 basket and bistratified cells and resembled CA1 OLM cells (Ali and Thomson, 1998; Maccaferri, 2005). In CA1, previous studies have described a pronounced sag and spike frequency adaptation in three classes of interneurons: OLM cells (Ali and Thomson, 1998), a CCK-immunopositive Schaffer-associated cell, and a CCK-immunopositive quadrilaminar cell (with soma at the SR/SLM border and axon arborizing in SO, SP, SR, and SLM) (Pawelzik et al., 2002). Like the CA2 basket and bistratified cells described here, these interneurons had sparsely spiny, horizontally oriented dendrites.

These are the first distinct population of PV-immunopositive basket cells that display a strongly adapting firing pattern and a pronounced sag in voltage responses to hyperpolarizing current to be described in hippocampus or neocortex. This suggests that a correlation between interneuronal firing patterns, target preferences, and calcium binding protein content is not absolute.

The majority of CA2 basket cells were CB immunonegative. However, the presence of other calcium binding proteins, or neuronal markers, which were not tested, may yet differentiate between the two types.

\section{Possible role of CA2 in the hippocampal circuitry and oscillatory rhythms}

The present study characterized for the first time CA2 interneurons. These interneurons display strikingly distinctive morphological and electrophysiological features, suggesting that this region may play a unique role in the hippocampal circuitry. It is becoming clear that CA2 represents more than just a CA1/CA3 transitional region. CA2 receives inputs directly from entorhinal cortex and amygdala and, in vivo, can directly activate CA1 independently of the CA3 subfield and in parallel with the trisynaptic pathway (Bartesaghi et al., 2006).

Postmortem studies have demonstrated a striking and selective decrease in the number of interneurons in CA2 in schizophrenics patients and increased $\mathrm{GABA}_{\mathrm{A}}$ receptor binding in the CA3/CA2 subfields that is not matched by increases in benzodiazepine receptors (Benes et al., 1997, 1998; Benes, 1999). The possibility that a "miswiring" of CA2 is involved in the onset of schizophrenia provides additional impetus to the characterization of CA2 interneurons.

CA2 interneurons may receive inputs from all three CA regions, as well as from the entorhinal cortex, amygdala, and possibly from the dentate gyrus and exert feedback inhibition in CA3 and feedforward inhibition in CA1. That these interneurons may coordinate activity across the three regions is an attractive possibility. In considering links between neighboring parts of CA3 and CA1 that would be provided by CA2 basket cells, the excitatory connections from CA3 to CA1 should also be considered. Projections from any part of CA3 extend widely across all CA subfields in all three dimensions but follow orderly gradients. CA3 pyramids within reach of $\mathrm{CA} 2$ basket cell axons project association 


\section{A}

CA1 BASKET CELL 040519

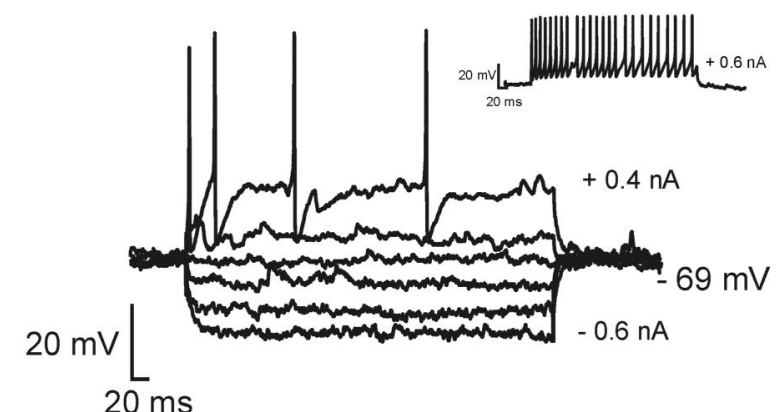

B CA2 BASKET CELL WITH RESTRICTED DENDRITIC AND AXONAL ARBOURS

040720

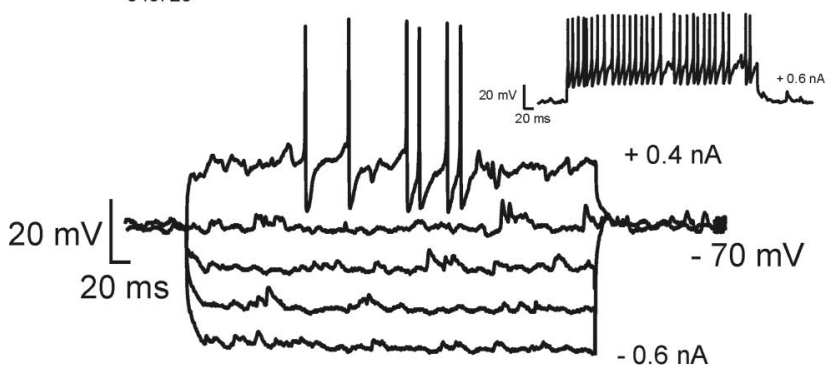

\section{CA2 BASKET CELL} WITH WIDE DENDRITIC AND AXONAL ARBOURS

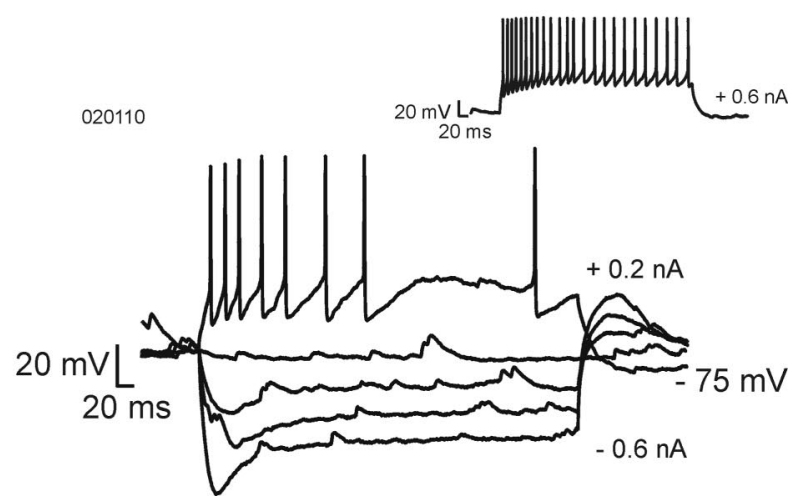

Figure 5. Electrophysiological characteristics of basket cells recorded in the CA1 and CA2 regions. $\boldsymbol{A}$, Voltage responses of a CA1 basket cell to hyperpolarizing and depolarizing current injection. $\boldsymbol{B}$, Voltage responses of a CA2 basket cell that had a narrow dendritic arbor. $\boldsymbol{C}$, Voltage responses of a $C A 2$ basket cell that had broad and horizontally oriented dendrites. In contrast to CA1 basket cells and to CA2 basket cells that were confined to CA2, this cell displayed significant spike frequency adaptation and a pronounced sag in its voltage response to hyperpolarizing current injection.

fibers throughout the transverse extent of CA3 but with bias toward the border with CA2. Their Schaffer collaterals project most densely to SO and deep SR of CA1, "just across the border into proximal CA1" and $0.5-1.0 \mathrm{~mm}$ in the temporal direction from that transverse plane (Ishizuka et al., 1990). Thus, CA2 basket cells, which might also be directly activated by the perforant path (Bartesaghi et al., 2006), may exert control over CA3 pyramids
A

\section{CA1 BISTRATIFIED CELL}

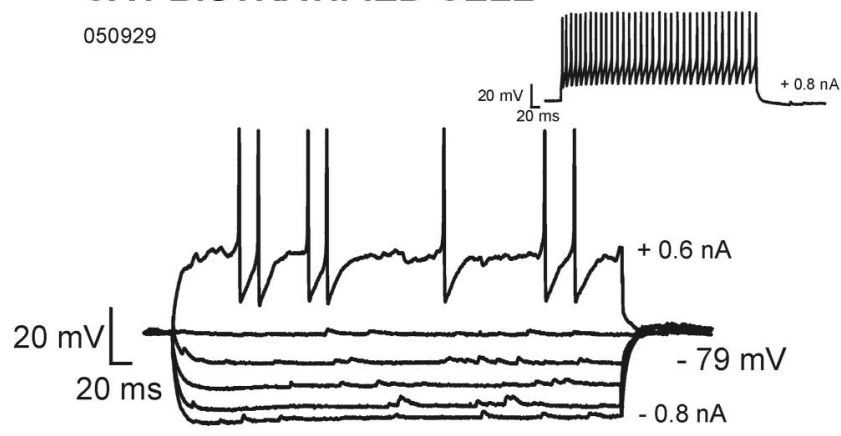
B CA2 BISTRATIFIED CELL WITH RESTRICTED DENDRITIC ARBOUR 040210

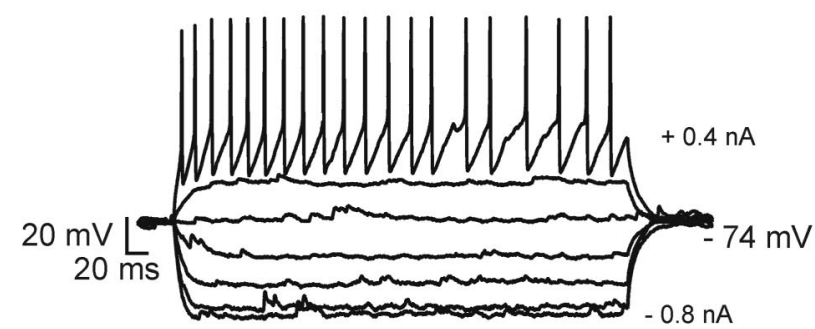

\section{CA2 BISTRATIFIED CELL WITH WIDE DENDRITIC ARBOUR}

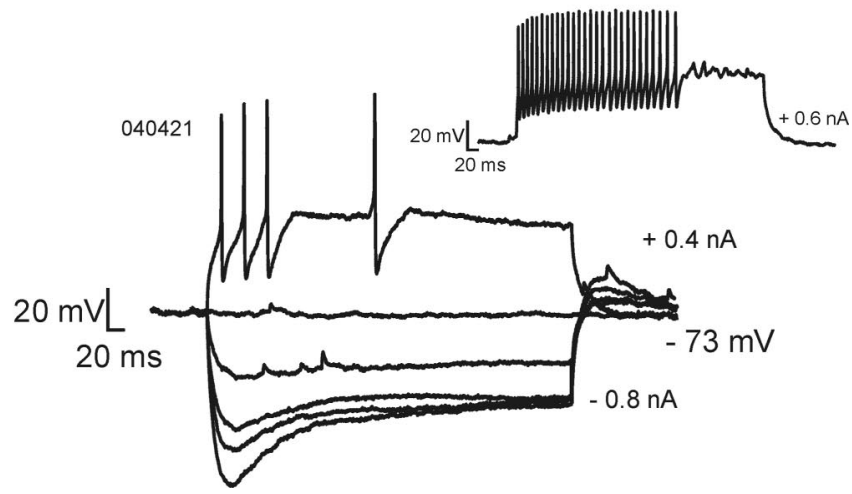

Figure 6. Electrophysiological characteristics of bistratified cells recorded in the CA1 and CA2 regions. $A$, Voltage responses of a $C A 1$ bistratified cell to hyperpolarizing and depolarizing current injection. $\boldsymbol{B}$, Voltage responses of a CA2 bistratified cell that had a narrow dendritic arbor. $C$, Voltage responses of a CA2 bistratified cell that had broad and horizontally oriented dendrites. In contrast to CA1 and CA2 bistratified cells with narrow dendritic arbors, this cell displayed significant spike frequency adaptation and a pronounced sag in its voltage response to hyperpolarizing current injection.

that excite broad regions of CA3 and CA1 but with bias in the transverse, although not perhaps in the septotemporal plane, toward regions also controlled by these basket cells. CA2 bistratified cells, conversely, could not be directly activated via the perforant path and would provide more delayed, disynaptic, feedforward inhibition to the dendritic regions of CA1 most densely innervated by these CA3 pyramids. 


\section{- CA1 Basket cells - CA1 Bistratified cells O CA2 Basket cells CA2 Bistratified cells}

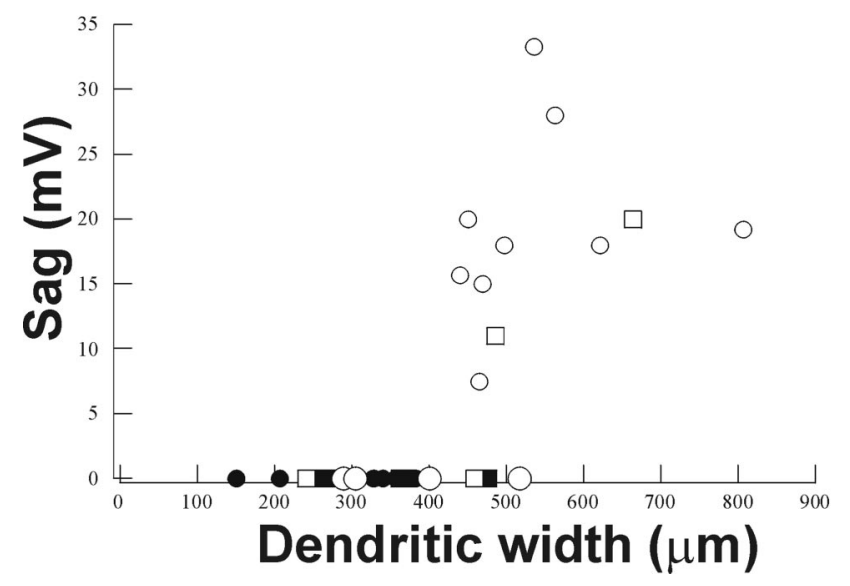

Figure 7. Correlation between the width of horizontally oriented dendrites and the presence of a sag in the voltage responses to hyperpolarizing current injection. All basket and bistratified cells with broad dendritic arbors displayed a sag in their voltage response to a current pulse of $-0.6 \mathrm{nA}$ (Spearman's test, $r=0.74 ; \alpha=0.05$ ).

CA2 is also unique in being the only CA region receiving input from the hypothalamic supramammillary nucleus (SUM). Because the SUM also projects to the medial septum (Vertes and McKenna, 2000), it has been proposed to play an important role in the modulation of hippocampal theta rhythm (Kirk and McNaughton, 1991). In addition, $I_{\mathrm{h}}$ is thought to contribute to theta oscillations in the entorhinal cortex (Dickson et al., 2000) and the septum (Kocsis and Li, 2004). Because CA2 interneurons can receive inputs from the SUM and from entorhinal cortex, express a pronounced sag, and have dendrites and axons extending into CA3 and CA1, they may contribute to the coordination of thetarelated activity across subfields. In contrast, CA2 interneurons that resemble CA1 interneurons, with dendrites and axons confined to their region of origin and fast electrophysiological characteristics, may play a more significant role in supporting localized gamma oscillations.

\section{References}

Ali AB, Thomson AM (1998) Facilitating pyramid to horizontal oriensalveus interneurone inputs: dual intracellular recordings in slices of rat hippocampus. J Physiol (Lond) 507:185-199.

Ali AB, Deuchars J, Pawelzik H, Thomson AM (1998) CA1 pyramidal to basket and bistratified cell EPSPs: dual intracellular recordings in rat hippocampal slices. J Physiol (Lond) 507:201-217.

Ali AB, Bannister AP, Thomson AM (1999) IPSPs elicited in CA1 pyramidal cells by putative basket cells in slices of adult rat hippocampus. Eur J Neurosci 11:1741-1753.

Baimbridge KG, Miller JJ (1982) Immunohistochemical localization of calcium-binding protein in the cerebellum, hippocampal formation and olfactory bulb of the rat. Brain Res 245:223-229.

Bartesaghi R, Gessi T (2004) Parallel activation of field CA2 and dentate gyrus by synaptically elicited perforant path volleys. Hippocampus 14:948-963.

Bartesaghi R, Migliore M, Gessi T (2006) Input-output relations in the entorhinal cortex-dentate-hippocampal system: evidence for a non-linear transfer of signals. Neuroscience 142:247-265.

Benes FM (1999) Evidence for altered trisynaptic circuitry in schizophrenic hippocampus. Biol Psychiatry 46:589-599.

Benes FM, Wickramasinghe R, Vincent SL, Khan Y, Todtenkopf MS (1997) Uncoupling of GABA(A) and benzodiazepine receptor binding activity in the hippocampal formation of schizophrenic brain. Brain Res 755:121-129.

Benes FM, Kwok EW, Vincent SL, Todtenkopf MS (1998) A reduction of nonpyramidal cells in sector CA2 of schizophrenics and manic depressives. Biol Psychiatry 44:88-97.

Braak E, Strotkamp B, Braak H (1991) Parvalbumin-immunoreactive structures in the hippocampus of the human adult. Cell Tissue Res 264:33-48.

Buhl EH, Szilagyi T, Halasy K, Somogyi P (1996) Physiological properties of anatomically identified basket and bistratified cells in the CA1 area of the rat hippocampus in vitro. Hippocampus 6:294-305.

Dickson CT, Magistretti J, Shalinsky MH, Fransen E, Hasselmo ME, Alonso A (2000) Properties and role of Ih in the pacing of subthreshold oscillations in entorhinal cortex layer II neurons. J Neurophysiol 83:2562-2579.

Frederickson CJ, Suh SW, Silva D, Frederickson CJ, Thompson RB (2000) Importance of zinc in the central nervous system: the zinc-containing neuron. J Nutr 130:1471S-1483S.

Freund TF, Buzsaki G (1996) Interneurons of the hippocampus. Hippocampus 6:347-470.

Gaarskjaer FB (1986) The organization and development of the hippocampal mossy fiber system. Brain Res 396:335-357.

Hughes DI, Bannister AP, Pawelzik H, Thomson AM (2000) Double immunofluorescence, peroxidase labelling and ultrastructural analysis of interneurons following prolonged electrophysiological recordings in vitro. J Neurosci Methods 101:107-116.

Ishizuka N, Weber J, Amaral DG (1990) Organization of intrahippocampal projections originating from CA3 pyramidal cells in the rat. J Comp Neurol 295:580-623.

Ishizuka N, Cowan WM, Amaral DG (1995) A quantitative analysis of the dendritic organization of pyramidal cells in the rat hippocampus. J Comp Neurol 362:17-45.

Kirk IJ, McNaughton N (1991) Supramammillary cell firing and hippocampal rhythmical slow activity. NeuroReport 2:723-725.

Kocsis B, Li S (2004) In vivo contribution of h-channels in the septal pacemaker to theta rhythm generation. Eur J Neurosci 20:2149-2158.

Lein ES, Callaway EM, Albright TD, Gage FH (2005) Redefining the boundaries of the hippocampal CA2 subfield in the mouse using gene expression and 3-dimensional reconstruction. J Comp Neurol 485:1-10.

Leranth C, Ribak CE (1991) Calcium-binding proteins are concentrated in the CA2 field of the monkey hippocampus: a possible key to this region's resistance to epileptic damage. Exp Brain Res 85:129-136.

Lorente de No R (1934) Studies on the structure of the cerebral cortex. II. Continuation of the study of the ammonic system. J Psychol Neurol 46:113-177.

Maccaferri G (2005) Stratum oriens horizontal interneurone diversity and hippocampal network dynamics. J Physiol (Lond) 562:73-80.

Ochiishi T, Saitoh Y, Yukawa A, Saji M, Ren Y, Shirao T, Miyamoto H, Nakata H, Sekino Y (1999) High level of adenosine A1 receptor-like immunoreactivity in the CA2/CA3a region of the adult rat hippocampus. Neuroscience 93:955-967.

Pawelzik H, Bannister AP, Deuchars J, Ilia M, Thomson AM (1999) Modulation of bistratified cell IPSPs and basket cell IPSPs by pentobarbitone sodium, diazepam and $\mathrm{Zn}^{2+}$ : dual recordings in slices of adult rat hippocampus. Eur J Neurosci 11:3552-3564.

Pawelzik H, Hughes DI, Thomson AM (2002) Physiological and morphological diversity of immunocytochemically defined parvalbumin- and cholecystokinin-positive interneurons in CA1 of the adult rat hippocampus. J Comp Neurol 443:346-367.

Ratzliff AD, Soltesz I (2001) Differential immunoreactivity for alphaactinin-2, an $N$-methyl-D-aspartate-receptor/actin binding protein, in hippocampal interneurons. Neuroscience 103:337-349.

Sekino Y, Obata K, Tanifuji M, Mizuno M, Murayama J (1997) Delayed signal propagation via CA2 in rat hippocampal slices revealed by optical recording. J Neurophysiol 78:1662-1668.

Sik A, Penttonen M, Ylinen A, Buzsaki G (1995) Hippocampal CA1 interneurons: an in vivo intracellular labeling study. J Neurosci 15:6651-6665.

Sirvanci S, Meshul CK, Onat F, San T (2003) Immunocytochemical analysis of glutamate and GABA in hippocampus of genetic absence epilepsy rats (GAERS). Brain Res 988:180-188.

Sloviter RS (1983) "Epileptic" brain damage in rats induced by sustained electrical stimulation of the perforant path. I. Acute electrophysiological and light microscopic studies. Brain Res Bull 10:675-697.

Somogyi P, Klausberger T (2005) Defined types of cortical interneurone 
structure space and spike timing in the hippocampus. J Physiol (Lond) $562: 9-26$.

Tamamaki N, Abe K, Nojyo Y (1988) Three-dimensional analysis of the whole axonal arbors originating from single CA2 pyramidal neurons in the rat hippocampus with the aid of a computer graphic technique. Brain Res 452:255-272.

Tucker MS, Khan I, Fuchs-Young R, Price S, Steininger TL, Greene G, Wainer BH, Rosner MR (1993) Localization of immunoreactive epidermal growth factor receptor in neonatal and adult rat hippocampus. Brain Res 631:65-71.

Vertes RP, McKenna JT (2000) Collateral projections from the supramammillary nucleus to the medial septum and hippocampus. Synapse 38:281-293.

Williams TE, Meshul CK, Cherry NJ, Tiffany NM, Eckenstein FP, Woodward
WR (1996) Characterization and distribution of basic fibroblast growth factor-containing cells in the rat hippocampus. J Comp Neurol 370:147-158.

Wyszynski M, Lin J, Rao A, Nigh E, Beggs AH, Craig AM, Sheng M (1997) Competitive binding of alpha-actinin and calmodulin to the NMDA receptor. Nature 385:439-442.

Young WS, Li J, Wersinger SR, Palkovits M (2006) The vasopressin $1 \mathrm{~b}$ receptor is prominent in the hippocampal area CA2 where it is unaffected by restraint stress or adrenalectomy. Neuroscience 143:1031-1039.

Zhao X, Lein ES, He A, Smith SC, Aston C, Gage FH (2001) Transcriptional profiling reveals strict boundaries between hippocampal subregions. J Comp Neurol 441:187-196. 